in this Newsletter to the advantage not only of the technical reader, but equally of a wider public. This first issue already sets the standard for the future editions. It includes brief progress reports on a variety of present-day problems under investigation at these several centres. Among these are exploration of the continental shelfNorth Sea and East Pacific; offshore drilling and onshore developments on the Guinea Coast, West Africa; a new clue to the origin of petroleum; the role of catalysts in promoting chemical reactions, based on the new conception that a catalyst ". . . does in fact undergo a chemical transformation, but returns to its former state having done so"; noise from flames; a new source of energy-developments in the fuel cell; the use of analogue computers in refinery design; work on molluscicides with the object of controlling the disease bilharziasis; the significance of organochlorine residues in human fat and wild animals; the fight against oil pollution at sea; and the control of Dutch Elm disease. It is on record in a modest footnote that the annual research budget for all Royal Dutch/Shell group companies is $£ 25$ million, while the total personnel employed in the research establishments is 6,000. This Newsletter may be good publicity but it is obviously destined to command attention of oil technologists as a medium for keeping abreast of contemporary research projects and results, at least in title, if not in epitome.

\section{The United States National Museum}

The report for the year ended June 30, 1964, of tho United States National Museum places on record the official opening on January 22, 1964, of the new Museum of History and Technology in Washington, D.C., by President Lyndon B. Johnson (Pp. viii +215 . Washington, D.C.: The United States National Museum, 1965). The displays for this ceremony included everyday life in the American past, American costume, farm machinery, railroads and vehicles. There was also a centrally placed Foucault pendulum and demonstrations are conducted in a pre-1855 machine shop. The reconstruction of a Renaissance clock-tower is particularly attractive. Accessions include a magneto-electric generator made in 1832 or 1833 for production of direct current in which a cam on the vertical shaft caused contact to be made on the crossed strips of copper first in one direction and then in the other; also the drum used at the funeral of the late President Kennedy. A Koryo Dynasty (A.D. 918-1392) Buddha, lent by the Republic of Korea, and a machine for coverlet-weaving are among the numerous new exhibits.

\section{The Linnean Society of London:} Officers and New Members of Council

AT the anniversary meeting of the Linnean Society of London, held on May 24, the following were elected officers for the session 1965-66: President, Dr. E. I. White; Treasurer, The Earl of Cranbrook; Secretaries, Dr. H. G. Vevers (zoology) and Mr. J. P. M. Brenan (botany); Editorial Secretary, Dr. John Smart; Vice-Presidents appointed were: The Earl of Cranbrook, Dr. R. W. J. Keay, Dr. D. M. Kermack, Prof. C. T. Ingold; New Members of Council elected, Mr. J. P. M. Brenan, Prof. J. G. Hawkes, Dr. Doris M. Kermack, Mr. B. W. Sparks, Prof. W. T. Williams.

Medals and Awards

The following medals were awarded: Linnean Gold Medals to Dr. J. Ramsbottom and Dr. J. Hutchinson; H. H. Bloomer Award (for outstanding contributions to biology by an amateur), to E. C. Wallace.

Foreign Members

The foreign members elected were: Dr. S. M. Bukasov, Prof. A. Frey-Wyssling, Prof. C. L. Hubbs and Prof. J. Léonard.
Unilever Inter-European Fellowships in Biochemistry

Dr. T. Nikkari and Dr. J. H. Ottoway have been named by the Biochemical Society as recipients of the first two European fellowships sponsored by Unilever Research. Dr. Nikkari, of the Department of Medical Chemistry, University of Turku, Finland, will work on the biosynthesis and function of hydroxy and unsaturated fatty acids in rat and human skin with Dr. A. T. James of the Unilever Research Laboratory, Colworth House, Bedford. Dr. Ottoway, of the Department of Biochemistry, University of Edinburgh, will be working on the function of mitochondria in energy metabolism in muscle with Dr. M. Klingenberg at the Physiologisch-chemisches Institut, University of Marburg, Germany.

Two Unilever fellowships in biochemistry, each worth $£ 1,200$, are to be awarded annually, tenable for one year only. They may be either for work in a laboratory in Europe by a British or British Commonwealth eitizen resident in the United Kingdom, or for work in the United Kingdom by a European national.

\section{University News:}

Imperial College of Science and Technology, London

The Governing Body of the Imperial College of Science has elected four former students and one of its members to fellowships of the College: Mr. A. H. Albu, Minister of State for Economic Affairs and Member of Parliament for Edmonton since 1948, student of mechanical engineering and motive power during 1920-23, member of the Governing Body during 1954-65; Sir Andrew Bryan, member of the Governing Body since 1949, chairman of the Mining Qualifications Board, president of the Institution of Mining Engineers during 1950-51; Sir Charles Mills Cawley, chief scientist at the Ministry of Power since 1959, student in the Department of Chemistry during 1926-29; Mr. R. J. Halsey, director of Cable and Wireless Ltd. since January 1965, student and later demonstrator of mechanical engineering and motive power during 1923-27, director of research of the General Post Office during 1958-64; Sir Gilbert Roberts, partner in Freeman, Fox and Partners since 1945, student of civil engineering during 1920-22, designer of large span bridges, including the Forth Road Bridge and the Severn Bridge.

Associateship of the Royal College of Science honoris causa has been conferred on Prof. H. Elliot, professor of physics.

Prof. J. Sutton, professor of geology, has been elected dean of the Royal School of Mines from October 1. Prof. P. M. S. Blackett has been appointed to a Senior Research Fellowship from October, on his retirement from the chair of physics.

Dr. C. Jaeger, consulting engineer to the English Electric Co., Rugby, and for many years associated with work at the Imperial College of Science and Technology in applied fluid mechanics and hydraulic structures, has been appointed the first visiting professor at the Imperial College. Under a new scheme, and with the approval of the University of London, the Imperial College of Science and Technology is conferring the title of visiting professor to Imperial College on a limited number of leading scientists and technologists from industry and government esteblishments. These visiting professors will spend an appreciable proportion of their time at the College, and will participate both in its academic work and in research.

\section{Queen Mary College, London}

The annual report of Queen Mary College, University of London, for the session 1963-64 (Pp. 131. London: Queen Mary College, 1965), outlines the plan for expanding the College, following on the Robbins report, to take a further 950 students during the next 5 years, with ultimate expansion to 3,000 by $1973--74$, compared with 1,502 in 